\title{
Interactive comment on "Aerosol radiative effect during the summer 2019 heatwave produced partly by an inter-continental Saharan dust outbreak. 1. Shortwave dust-induced direct impact” by Carmen Córdoba-Jabonero et al.
}

Anonymous Referee \#3

Received and published: 19 January 2021

The authors present a case study on the use of ground-based measurements from various sensors (sunphotometers and lidars) and a radiative transfer model to calculate the direct radiative effect of fine and coarse mode dust particles, separately, over Barcelona, Spain and Leipzig, Germany. Overall, this is a nice paper that merits to be published in ACP after the authors address my comments and also the comments of the other reviewers. Below, please find my major and minor comments:

1) English should be improved in the text. I believe the authors could do several improvements by going through the text several times. 
2) Line 26-27. Please rephrase this sentence. You might consider breaking it into two sentences.

3) Line 36. Please replace concerning with another word (e.g. with important).

4) Line 37. Relies instead of rely.

5) Line 50. Please give a reference here if there is any. Otherwise, rephrase.

Interactive

comment

6) Line 52. Dust emissions are very uncertain and may be even higher (also much lower). See the paper of Huneeus et al. (2011). Quite a significant part of them is of anthropogenic origin (Ginoux et al., 2012).

7) Line 57-59. You need a reference here. In a very recent study, Akritidis et al. (2020) present a very massive event of dust transport over Europe. Another study that could be also cited is Osborne et al. (2019).

8) Line 96. Is this separation between coarse and fine mode aerosols or dust and no-dust? Is there a possibility of having other aerosol components into the coarse mode?

9) Line 159. Please give the wavelengths at which the radiative transfer is implemented. Is there a specific spectral resolution of the model?

10) Line 203. Please define the term frequencies. How were they calculated?

11) Line 250. Remove "on"

12) Personally, I do not like very much the use of $J$ instead of January.

13) As a general comment. The aging of dust is probably expected to modify the optical properties of dust. I would like to see a discussion on that in the paper.

Printer-friendly version

14) The use of two symbols for the single scattering albedo and asymmetry factor is confusing, i.e. AsyF and g.

Discussion paper

15) Please be more specific about the albedo data used. Are they part of the standard 


\section{AERONET product?}

16) It would be interesting to see a comparison of the radiative calculations with climatological values appearing in recent studies (e.g. Nabat et al., 2014 and Tsikerdekis et al., 2019). In this way, the reader will be able to evaluate the high or low instantaneous radiative effect values appearing in the paper.

17) Personally, I do not like some figures. E.g. Figure 2 or 5 might be polished a little bit. However, this is not a must.

18) Most probably the radiative effect of fine and coarse mode dust when added will not be equal to the total dust if a simulation is done for the total dust properties due to nonlinearities. This stems from the fact that dust particles are mingled and not separated in the atmosphere. I would appreciate a discussion on this from the authors.

\section{References}

Huneeus, N., Schulz, M., Balkanski, Y., Griesfeller, J., Prospero, J., Kinne, S., Bauer, S., Boucher, O., Chin, M., Dentener, F., Diehl, T., Easter, R., Fillmore, D., Ghan, S., Ginoux, P., Grini, A., Horowitz, L., Koch, D., Krol, M. C., Landing, W., Liu, X., Mahowald, N., Miller, R., Morcrette, J.-J., Myhre, G., Penner, J., Perlwitz, J., Stier, P., Takemura, T., and Zender, C. S.: Global dust model intercomparison in AeroCom phase I, Atmos. Chem. Phys., 11, 7781-7816, https://doi.org/10.5194/acp-11-7781-2011, 2011.

Ginoux, P., Prospero, J. M., Gill, T. E., Hsu, N. C., and Zhao, M.: Global-scale attribution of anthropogenic and nat-ural dust sources and their emission rates based on MODIS Deep Blue aerosol products, Rev. Geophys., 50, RG3005, https://doi.org/10.1029/2012RG000388, 2012.

Akritidis, D., Katragkou, E., Georgoulias, A. K., Zanis, P., Kartsios, S., Flemming, J., Inness, A., Douros, J., and Eskes, H.: A complex aerosol transport event over Europe during the 2017 Storm Ophelia in CAMS forecast systems: analysis and evaluation, Atmos. Chem. Phys., 20, 13557-13578, https://doi.org/10.5194/acp-20-13557-2020,

\section{Discussion paper}




\section{0.}

Osborne, M., Malavelle, F. F., Adam, M., Buxmann, J., Sugier, J., Marenco, F., and ACPD Haywood, J.: Saharan dust and biomass burning aerosols during ex-hurricane Ophelia: observations from the new UK lidar and sun-photometer network, Atmos. Chem. Phys., 19, 3557-3578, https://doi.org/10.5194/acp-19-3557-2019, 2019.

Nabat, P., Somot, S., Mallet, M., Sevault, F., Chiacchio, M., and Wild, M.: Direct and semi-direct aerosol radiative effect on the Mediterranean climate variability using a coupled regional cli-mate system model, Clim. Dyn., 44, 1-29, https://doi.org/10.1007/s00382-014-2205-6, 2014.

Tsikerdekis, A., Zanis, P., Georgoulias, A. K., Alexandri, G., Katragkou, E., Karacostas, T., and Solmon, F.: Direct and semi-direct radiative effect of North African dust in present and future regional climate simulations, Clim. Dynam., 53, 4311-4336, https://doi.org/10.1007/s00382-019-04788-z, 2019.

Interactive comment on Atmos. Chem. Phys. Discuss., https://doi.org/10.5194/acp-2020-1013, 2020. 